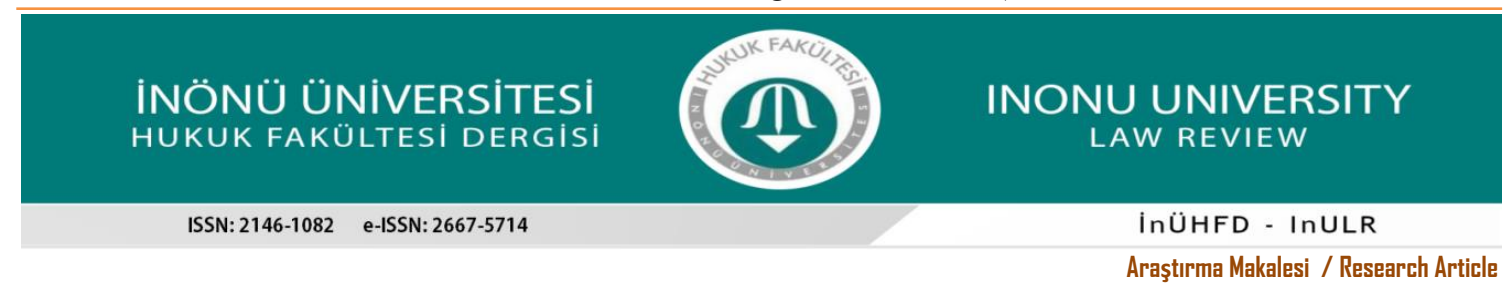

\title{
SENDİKAL HAKLARIN KULLANILMASININ ENGELLENMESİ SUÇU
}

\author{
PREVENTION OF USE OF SYNDICAL RIGHTS
}

\author{
Devrim AYDIN* ${ }^{*}$ (i)
}

\begin{tabular}{l} 
Makale Bilgi \\
\hline Gönderi: 05/08/2021 \\
Kabul : 22/12/2021 \\
Anahtar Kelimeler \\
\hline Sendika, \\
Sendikal Faaliyet, \\
Sendikal Haklar, \\
Çalışma, \\
İsçi, \\
Suç, \\
Ceza.
\end{tabular}

\begin{abstract}
Özet
https://dai.org/l0.21492/inuhfd.979237 do

İşçilerin yanı sıra işverenlerin de sendikal faaliyette bulunabilme hakkı, uluslararası sözleşmeler ve Anayasamızda sosyal ve ekonomik haklar arasında yer almaktadır. Bireylerin sendikaya üye olmalarının, bireysel sendika haklarının kapsamı ile sendikaların faaaliyetlerinin ayrıntıları 6356 sayılı Sendikalar ve Toplu İş Sözleşmesi Kanunu ile 4688 sayılı Kamu Görevlileri Sendikaları ve Toplu Sözleşme Kanunu'ndadır. İlgili mevzuatta içeriği belirlenmiş olan bireysel ve kolektif sendikal hakların ihlal edilmesinin engellenmesi ve bu hakların ceza hukuku yoluyla korunması amaciyla 5237 sayılı Türk Ceza Kanunu'nda (TCK) hürriyete karşı suçlar arasında "sendikal hakların kullanılmasının engellenmesi" suçu (m.118) düzenlenmiştir. Bu maddede birbirini tamamlayan iki ayrı suç yer almaktadır. Birinci fikrada "bireysel sendikal hakların kullanılmasının engellenmesi” suçu düzenlenmiştir. Bu düzenlemeyle, bireylerin herhangi bir baskı görmeden sendikal haklarını kullanabilmeleri korunmak istenmiştir. Maddenin ikinci fikrasında ise "sendika tüzel kişiliğinin faaliyetlerinin engellenmesi" suçu düzenlenmiştir. $\mathrm{Bu}$ fikradaki düzenlemeyle kolektif sendikal hakların korunması amaçlanmıştır. Birbirlerini tamamlayıcı nitelikteki bireysel ve kolektif sendika hakkının ihlali TCK m.118'de birlikte düzenlenmiştir. Ancak bu hükümde maddi unsurları, mağdurları ve maddi konuları birbirinden farklı iki ayrı suç yer almaktadır. Bu çalışmada TCK m.118'de düzenlenmiş olan bireylerin ve sendikaların sendikal haklarının kullanılmasının engellenmesi suçu konu edilmiştir.
\end{abstract}

Article Info

Received: 05/08/2021

Accepted: 22/12/2021

Keywords

Syndicate,

Syndical Activities,

Syndical Rights,

Labour,

Worker,

Crime,

Punishment.
Abstract

The right to engage in syndical activities is regulated in international conventions and in Turkish Constitution among social and economic rights. Today, employers, as well as workers, have the right to engage in syndical activities. In Turkish law, the membership of individuals to syndicates, individual syndical rights and the scope of the activities of syndicates are regulated in the Law No. 6356 and the Law No. 4688. In order to protect individual and collective syndical rights in the relevant legislation through criminal law, the crime of "preventing of use of syndical rights" is regulated in the Turkish Criminal Law (art. 118). In the first paragraph of the provision, threatening or coercing persons to force them not to exercise their union rights is regulated as a crime. In the second paragraph, forcibly or unlawfully preventing the activities of the syndicate is regulated as a crime. In art. 118, there are two crimes that are complement to each other but differ from each other in terms of legal issues, material elements and victims.

* Doç. Dr., Ankara Üniversitesi, Siyasal Bilgiler Fakültesi, Ceza ve Ceza Muhakemesi Hukuku.

Atıf Şekli | Cite As: AYDIN Devrim, "Sendikal Hakların Kullanılmasının Engellenmesi Suçu”, İnüHFD, 12(2), 2021, s.791-807. İntihal

| Plagiarism: Bu çalışma intihal programında kontrol edilmiş ve en az iki hakem incelemesinden geçmiştir. | This article has been controlled via a plagiarism software and reviewed by at least two blind referees 


\section{EXTENDED SUMMARY}

Republic of Turkey is a member of International Labor Organization (ILO) and is party to the European Convention on Human Rights (ECHR). According to the International Labor Organization Conventions and the European Convention on Human Rights, workers and employers have the right to engage in union activities in order to protect their interests in business life. In accordance with the requirements of being a party to these international conventions, the right of employers as well as workers to establish and join syndicates in order to protect their own interests is guaranteed in the Constitution of the Republic of Turkey art. 51. According to art 51, "Employees and employers have the right to form unions and higher organizations, without prior permission, and they also possess the right to become a member of a union and to freely withdraw from membership, in order to safeguard and develop their economic and social rights and the interests of their members in their labour relations. No one shall be forced to become a member of a union or to withdraw from membership." The details of establishing a syndicate, being a member of a syndicate and the powers of syndicates are regulated in the Law on Trade Unions and Collective Bargaining No. 6356 and the Law on Public Servants Unions and Collective Bargaining No. 4688. The crime of prevention of use of syndical rights is regulated as a crime in Turkish Criminal Code art. 118 among the "crimes against freedom" in the seventh chapter.

In article 118, in the first paragraph, preventing individuals from exercising their syndical rights, and in the second paragraph, preventing the activities of a syndicate established according to the laws are regulated as a crime. According to art. 118/1

"A person who uses force or threats in order to compel another person to be, or not to

be, a member of a trade union, to attend or not to attend activities of a trade union, to

leave a trade union or to leave a position of management of a trade union shall be

sentenced to a penalty of imprisonment for a term of six months to two years."

With this regulation, it is aimed to protect both individual and collective freedom of association within the same article. The legal subject of the crime of preventing the right to syndical activities regulated in the first paragraph is the right to establish a syndicate, to organize within a syndicate and to participate in syndical activities, which are guaranteed in international conventions and the Turkish Constitution. With this article, the unlawful violation of the rights of individuals to be a member of a syndicate, to engage in syndical activities, to take part in union management and to resign from the syndicate of which they are a member, without any unlawful intervention, is punished. The perpetrator of this crime can be any natural person. The victim of the crime is the real person who is forced or threatened to form a syndicate, becoming a member of a syndicate, participate in syndical activities or take advantage of the opportunities of the syndicate. In order for the crime in the first paragraph to take place, the victim's right to unionize must be prevented by threatening or coercive behavior.

In the second paragraph of the article, violation of the activities of the syndicate's legal entity is regulated as a crime. According to art. 118/2

"In the event that the activities of a trade union are prevented by the use of force, threats, or by means of any other unlawful act, a penalty of imprisonment for a term of one to three years shall be imposed."

The legal subject of this crime is the public interest of the syndicate's legal entity in the activities indicated in the relevant legislation. Although confederation activities are not explicitly mentioned in the text of the law, it should be accepted that the right of syndicate confederations to engage in syndical activities is also protected by this provision, since syndicates may be organized within the body of the confederation. The perpetrator of this crime is any natural person, and the victim of the crime is the syndicate's legal entity. This crime may be committed by threat, force or any other unlawful act.

Situations that increase or mitigate the punishment for crimes against freedom is regulated in the common provision art. 119. The crime of preventing the use of syndical rights (art. 118) is not listed in commom art. 119. Thus it would be against the principle of legality to apply a reason that increases the penalty during the commission of the crime of preventing the use of syndical rights. Since an aggravating condition in the common provision may also be in question while committing the crime of preventing the use of syndical rights, this crime should be added to the crimes listed in common art. 119.

The duty of prosecuting both crimes continues in the Criminal Court of First Instance. Since the upper limit of the penalty in the first paragraph requires a prison sentence of two years or less, it is subject to a simple trial procedure. 


\section{GİRiş}

Çalışma hakkı, çalışma özgürlüğü ve sendikal faaliyet hakları çalışma hayatında birbirini tamamlayan, birbiriyle sıkı ilişkileri olan hak ve özgürlüklerdir. Bunların tümü uluslararası sözleşmeler ve Anayasamızda sosyal ve ekonomik haklar arasında yer almaktadır. Çalışma hakkı; özgürce iş edinmeyi, adil çalışma koşullarının sağlanmasını, güvenli ve sağlıklı çalışma koşullarının oluşturulmasını, örgütlenme özgürlüğünü, ayrımcılık yasağını ve işçinin haksız feshe karşı korunmasını kapsamaktadır. ${ }^{1}$ Çalışma özgürlüğü ise çalışmanın bir müdahale olmadan sürdürülebilmesi, kişinin işini ve iş yapma biçimini seçebilmesi, kişilerin başkalarının engellemesi olmadan çalışabilmesi konularını kapsar.

Sendikalar, 19. yüzyılda işçilerin işvene karşı daha güçlü olmak için bünyesinde örgütlendikleri tüzel kişiler olarak ortaya çıkmıştır. ${ }^{2}$ Günümüzde işçilerin yanı sıra işverenler de kendi menfaatlerini korumak için sendika çatısı altında örgütlenme hakkına sahiptirler. Bu nedenle sendika; işçilerin ya da işverenlerin ayrı ayrı olmak üzere iş, kazanç, toplumsal ve kültürel konular yönünden çıkarlarını korumak, yeni haklar sağlamak ve onları daha da geliştirmek amacıyla kurdukları hukuki bir mesleki birlik olarak tanımlanabilir. ${ }^{3}$ Sendika, 6356 sayılı Sendikalar ve

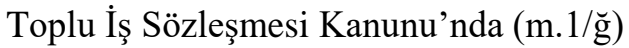

"İşçilerin veya işverenlerin çalışma ilişkilerinde, ortak ekonomik ve sosyal hak ve çıkarlarını korumak ve gelişstirmek için en az yedi iş̧̧ veya işverenin bir araya gelerek bir işkolunda faaliyette bulunmak üzere oluşturdukları tüzel kişiliğe sahip kuruluşlar"

şeklinde tanımlanmıştır.

Sendika kurma ve sendikaya üye olma hakkı, Uluslararası Çalışma Örgütü (ILO) Sözleşmeleri'nin yanı sıra Avrupa İnsan Hakları Sözleşmesi (AİHS, m.11) ve Anayasamızda güvence altına alınmıştır. Türkiye'nin de üye olduğu Uluslararası Çalışma Örgütü'nün bu konudaki başlıca sözleşmeleri; 87 sayılı Sendika Özgürlüğü ve Sendika Hakkının Korunması Sözleşmesi, 98 sayılı Örgütlenme ve Toplu Görüşme Hakkı İlkelerinin Uygulanması Sözleşmesi ve 151 sayılı Kamu Hizmetinde Örgütlenme Hakkı Sözleşmesidir.

Sendikal faaliyet hakk1, AİHS m.11'de;

"Herkes barış̧̧l olarak toplanma ve dernek kurma hakkına sahiptir. Bu hak, çıkarlarını korumak amacıyla başkalarıyla birlikte sendikalar kurma ve sendikalara üye olma hakkını da içerir." şeklinde düzenlenmiştir.

Sendikal faaliyet hakk1, Anayasamızda, m.51'de;

"Çalışanlar ve işverenler, üyelerinin çalışma ilişsilerinde, ekonomik ve sosyal hak ve menfaatlerini korumak ve geliştirmek için önceden izin almaksızın sendikalar ve üst kuruluşlar kurma, bunlara serbestçe üye olma ve üyelikten serbestçe çekilme haklarına sahiptir. Hiç kimse bir sendikaya üye olmaya ya da üyelikten ayrlmaya zorlanamaz." şeklinde düzenlenerek sendika kurmak ve sendikaya üye olmak hakkı güvenceye alınmıştır.

Anayasa m.51/3'e göre;

"Sendika kurma hakkinın kullanılmasında uygulanacak şekil, şart ve usuller kanunda gösterilir."

Anayasa m.51/4'teyse

"İ̧̧̧̧ niteliği taşımayan kamu görevlilerinin bu alandaki haklarının kapsam, istisna ve sinırlarl gördükleri hizmetin niteliğine uygun olarak kanunla düzenlenir."

denilerek işçi sıfatını taşımayan kamu görevlilerinin sendikal örgütlenmelerinin esaslarının kanunla düzenleneceği belirtilmiştir.

Bireylerin sendikaya üye olmaları ve bireysel sendika haklarıyla sendikaların faaaliyetlerinin kapsamı 6356 sayılı Sendikalar ve Toplu İş Sözleşmesi Kanunu (m.2) ile 4688 sayılı Kamu Görevlileri Sendikaları ve Toplu Sözleşme Kanunu'nda düzenlenmiştir. 4688 sayılı Kanun'nda (m.15) sendika üyesi olması yasaklanan kamu görevlileri sayılmışır.

\footnotetext{
${ }^{1}$ KAYA, Pir Ali/ULAŞ, Işın/YILMAZER, Ertuğrul: “Uluslararası İnsan Hakları Hukukunda Çalışma Hakkı”, Sosyal Siyaset Konferanslar1 Dergisi, (70), 2016, s.62.

2 Bkz. ERSOY, Uğur: "Sendikal Hakların Kullanılmasının Engellenmesi Suçu (TCK m.118)”, Gazi Üniversitesi Hukuk Fakültesi Dergisi, (2), 2016, s.473.

${ }^{3}$ Bkz. YARSUVAT, Duygun: Çalı̧̧ma Ceza Hukuku, Sendika Özgürlüğüne Karşı Suçlar, Kanunsuz Grev ve Lokavt Suçları, Sermet Matbaası, İstanbul 1978, s.22 vd.; AYDIN, Mesut: "1982 Anayasasında Sendika Kurma Hakkı ve Sınırlanması”, İstanbul Medipol Üniversitesi Hukuk Fakültesi Dergisi, (2), 2016, s.63.
} 
6356 sayılı Kanun m.17/3'’teki

"Sendikaya üye olmak serbesttir. Hiç kimse sendikaya üye olmaya veya olmamaya zorlanamaz."

şeklindeki hükümle sendikaya üye olmada serbestlik ilkesi benimsenmiştir. ${ }^{4}$ Ancak mevzuatımızda avukatlık, noterlik, hekimlik, mimarlık gibi diğer mesleki örgütlere üyelik zorunludur.

Uluslararası sözleşmeler ve Anayasamızda güvenceye alınmış olan sendikal hakların ceza hukuku yoluyla korunması yönünde 765 sayılı mülga TCK'da açık bir düzenleme yoktu. Yürürlükteki 5237 sayılı TCK'da, sendikal hakların kullanılmasının engellenmesi, "Kişilere Karşı Suçlar" başlıklı ikinci kısımda, "Hürriyete Karşı Suçlar" başlıklı yedinci bölümde ayrı bir suç türü olarak düzenlenmiştir. TCK m.118'deki düzenlemeyle hem bireysel hem de kolektif sendika hakk1 korunmak istenmiştir. Birinci fikrada, kişilerin herhangi bir baskı görmeden sendikal haklarını kullanabilmeleri korunmaktadır. ${ }^{5}$ Bireysel sendika hakkı öncelikle bireyin sendikaya üye olup olmamak yönündeki iradesini kapsar. Sendika üyelerinin üyesi oldukları sendikanın faaaliyetlerine katılıp katılmamak ya da sendikadan istifa etmek yönündeki iradeleri de bireysel sendika özgürlüğü kapsamındadır. Maddenin ikinci fikrasındaysa yasalara göre kurulmuş olan bir sendikanın faaliyetlerinin engellenmeden devam edebilmesi güvenceye alınmıştır.

Ülkemizde sendikalar, konfederasyonlar bünyesinde örgütlenebilirler. 2821 sayılı Sendikalar Kanunu m.26'ya göre bir konfederasyona üye olmak sendikanın genel kurulunun kararına bağlıdır. Buna göre, sendikaların bir konfederasyona üye olmaları zorunlu değildir. 6356 sayılı Kanun'da konfederasyon,

"değişik işkollarında en az beş sendikanın bir araya gelerek oluşturdukları tüzel kişiliğe sahip kuruluş"

şeklinde tanımlanmıştır. Kanun metninde açıkça belirtilmiş olmasa da sendikaların üst kuruluşu olan konfederasyonların faaliyetlerinin engellenmeden devam edebilmesinin de bu fikra kapsamında korunduğunu kabul etmek gerekir. ${ }^{6}$

Görüldügü üzere TCK m.118'de korunan hukuki yararları, maddi unsurları ve mağdurları birbirinden farklı iki ayrı suç düzenlenmiştir. Korunan hukuki yararları dolayısıyla birbirlerini tamamlayıcı nitelikteki bireysel ve kollektif sendikal haklara karşı işlenen iki ayrı suçun aynı madde içinde birlikte düzenlenmiş olması isabetlidir.

\section{KISŞILLERIN SENDİKAL HAKLARININ KULLANILMASININ ENGELLENMESİ (TCK m.118/1)}

\section{A. Genel Açıklamalar}

"Sendikal hakların kullanılmasının engellenmesi" başlıklı TCK m.118/1

"Bir kimseye karşı bir sendikaya üye olmaya veya olmamaya, sendikanın faaliyetlerine katılmaya veya katılmamaya, sendikadan veya sendika yönetimindeki görevinden ayrılmaya zorlamak amacıyla, cebir veya tehdit kullanan kişi, altı aydan iki yıla kadar hapis cezası ile cezalandirllır."

şeklindedir. Madde gerekçesinde

"Bir kimseye karşı cebir veya tehdit kullanılarak, bir sendikaya üye olmaya veya olmamaya, sendikanin faaliyetlerine katılmaya veya katılmamaya ya da sendikadan veya sendika yönetimindeki görevinden ayrlmaya zorlanmanın suç olarak düzenlendiği; suçun tamamlanmış şekline göre cezaya hükmedilebilmesi için, cebir veya tehdide maruz kalan kişinin sendikaya üye olması veya olmaktan vazgeçmesi, sendikanın faaliyetlerine katılması veya katılmaktan vazgeçmesi ya da sendikadan veya sendika yönetimindeki görevinden ayrlmasinin gerekmemektedir."

şeklindeki açıklamalarla suçun unsurlarına ilişkin genel bilgiler verilmiştir. ${ }^{7}$

\footnotetext{
${ }^{4}$ AYDIN, s.64.

5 EVIK, Ali Hakan: "Sendikal Hakların Kullanılmasının Engellenmesi Suçu”, İstanbul Ticaret Üniversitesi Sosyal Bilimler Dergisi, (10), 2006, s.206.

${ }^{6}$ BAYRAKTAR, Köksal/YILDIZ, Ali Kemal/KESKIN KIZİROĞLU, Serap/ZAFER, Hamide ve diğerleri: Özel Ceza Hukuku, C. 3, Onikilevha Yay., İstanbul 2018, s.290; ERSOY, s.479; SOYER, Sesim: "İş ve Çalışma, Hürriyetinin İhlali ile Sendikal Hakların Kullanılmasının Engellenmesi Suçlarına İlişkin Bazı Düşünceler”, Hukuki Perspektifler Dergisi, (7), 2006, s.102.

7 Kanunun gerekçesi için bkz. Adalet Bakanlığı, 5237 sayılı Türk Ceza Kanunu tanıtım sayfası için bkz. "http://www.ceza-bb.adalet.gov.tr."
} 
Bu suçun hukuki konusunu uluslararası sözleşmeler ve anayasada güvence altına alınmış olan sendika kurmak, sendika bünyesinde örgütlenmek ve sendikal faaliyetlere katılmak hakk1 oluştururur. Böylece kişilerin herhangi bir hukuka aykırı müdahale olmaksızın sendika üyesi olup olmamak, sendikal faaliyette bulunup bulunmamak, sendika yönetiminde görev alıp almamak ve üyesi oldukları sendikadan istifa edebilmek yönündeki hakları güvence altına alınmaktadır. ${ }^{8}$ Sendika kurup sendikaya üye olmak ve sendikal faaliyetlere katılmak olumlu ya da pozitif sendika özgürlüğ̈̈; sendikaya üye olmamak, sendikal faaliyete katılmamak ya da sendikadan istifa edebilmek ise olumsuz ya da negatif sendika özgürlüğü olarak da nitelenmektedir. ${ }^{9}$ Bu düzenlemeyle doğrudan, bireylerin sendikal haklarının yanı sıra çalı̧̧ma hayatının barışçıl biçimde sürdürülmesi de korunmaktadır. ${ }^{10}$

\section{B. Suçun Faili, Mağduru ve Maddi Konusu}

$\mathrm{Bu}$ suç fail açısından herhangi bir özellik göstermez. Herhangi bir gerçek kişi suçun faili olabilir. Birinci fikradaki suçun mağduru ise sendika kurmak, sendika üyesi olmak, sendikal faaliyetlere katılmak hakkı olan gerçek kişidir. ${ }^{11}$ Suçun faili ve mağduru sendika üyesi olmayan bir kişi olabileceği gibi, sendikanın üyesi de olabilir. ${ }^{12}$ Suçun mağduru ile failinin aynı işyerinde çalışan kişiler olması, failin işveren ya da işyerinde amir sıfatını taşıyan kişi olması muhtemeldir. Somut olaylarda sıklıkla suçun faili ile mağduru aynı işyerinde çalışan rakip sendika üyeleridir. Kimi hallerdeyse fail, sendika üyesi işçiyi sendikadan istifa etmesi amacıyla işten atmakla tehdit eden işveren ya da amir pozisyonundaki kişilerdir. Yargıtay'ın

"Suça konu işyerinde üretim müdürü olarak görev yapan sanık C. D.'in, yine iş yeri yönetiminde bulunan sanı A. Ç.'nun sendikal faaliyetlerde bulunan iş̧̧ilerin tespitine yönelik talimat verdiği, iş yerinde; servis sorumlusu olarak çalışan sanık T. C.'ın, bölüm sorumlusu sanık F. C.'in ve işçi olarak çalışan Z. G.'in, verilen talimat doğrultusunda sendikaya üye olan işçilerin tespitine çalıştıkları ve sendikaya üye olduğunu tespit ettikleri iş̧̧ileri, iş yeri yönetimine bildirdikleri, sanıklar C. D. ve A. Ç.'nun da katılanların da arasında bulunduğu bir kısım işçiyi performans yetersizliğini bahane göstererek işten çıkardıkları, katılanların açmış oldukları işe iade davalarının, 'feshin sendikal sebeplerle yapildı ̆̆ yolunda kanaat hasil olmasi' sebebiyle kabul edildiği anlaşılmakla; sendika üyesi olan işçilerin sendikal haklarını kullanmalarına engel olma, sendikalı olan ve olmayan işçiler arasında ayrım yapma ve bu işçilere baskl yaparak sendikadan istifa etmeye, sendikaya üye olmamaya zorlama şeklinde gerçekleşen eylemlerinin 5237 Sayıl TCK'nın 118/1. maddesindeki suçu oluşturacağl gözetilmelidir."

şeklindeki kararı bu durumun bir örneğidir. ${ }^{13}$

Sendika üyelerinin, yönetici olmak isteyen bir diğer üyeyi yönetici olmak fikrinden vazgeçmesi için tehdit etmeleri, sendika üyesi olan kişinin sendikanın faaliyetlerine katılmasını engellemeleri örneklerinde olduğu gibi, fail ve mağdur aynı sendikanın üyesi de olabilir. Sendika üyelerinin bir kişiyi sendika üyesi olması için tehdit etmeleri halindeyse failler sendika üyesiyken, mağdur sendika üyesi olmayan bir kişidir. ${ }^{14}$ Suçun failinin ya da mağdurunun sendika üyesi olup olmaması, failin işveren ya da işyerinde amir pozisyonunda olup olmaması suçun kurucu unsuru ya da nitelikli hali olarak düzenlenmemiştir.

Hukukumuzda işçiler ve kamu görevlilerinin sendikal hakları iki ayrı kanunda düzenlenmiş olsa da suçun mağduru olmak bakımından işçi ve kamu görevlileri arasında herhangi bir fark yoktur. Bu haklar kişiye sıkı sıkıya bağlı siyasal haklar arasında olduğundan, kişinin bu haklarını kullanmak için zorlanması halinde de mağdur olacağı açıktır.

Anayasa m.51'de düzenlenmiş olan sendikal haklar belli koşulları taşıyan yurttaşlara tanınmıştır. 6356 sayılı Kanun'nda (m.6)'da;

\footnotetext{
${ }^{8}$ BAYRAKTAR/KİZIROĞLU/YILDIZ/ZAFER ve diğerleri, s.286-287; ÖZEN, Mustafa: "Bireysel Sendika Özgürlüğü ve Sendikal Hakların Kullanılmasının Engellenmesi Suçu”, Legal İş ve Sosyal Güvenlik Hukuku Dergisi, (46), 2015, s.50.

${ }^{9}$ Bkz. MAHİROĞULLLARI, Adnan: Dünyada ve Türkiye'de Sendikacılık, Ekin Yay., Bursa 2013, s.10; ERDOĞAN, Irmak: "Ceza Hukukunun Sendikasızlaştırmayla Mücadelesi: Sendikal Hakların Kullanılmasının Engellenmesi Suçu”, Galatasaray Üniversitesi Hukuk Fakültesi Dergisi, (2), 2015, s.71; ARGUN, Fazilet Nurel: "Sendikal Hak ve Özgürlüklerin Hukuki Niteliği”, Türkiye Barolar Birliği Dergisi, 1, 1995, s.9.

10 BAYRAKTAR/KİİIIOĞLU/YILDIZ/ZAFER ve diğerleri, s.287; FINCAN, Müslüm: "Sendikal Hakların Kullanılmasının Engellenmesi Suçu”, Türkiye Barolar Birliği Dergisi, (136), 2018, s.49.

${ }^{11}$ SOYER, s.102.

${ }^{12}$ Bkz. EVIK, s.207.

${ }^{13}$ Yargıtay 18. Ceza Dairesi’nin 10.02.2016 tarih ve 2015/7995 E., 2016/2433 K. sayılı kararı için bkz. Kazancı İçtihat Program1.

${ }^{14}$ BAYRAKTAR/KİZİRİĞLU/YILDIZ/ZAFER ve diğerleri, s.288-289.
} 
"Fiil ehliyetine sahip ve fiilen çalışan gerçek veya tüzel kişiler sendika kurma hakkina sahiptir. Ancak 26/9/2004 tarihli ve 5237 sayll Türk Ceza Kanununun 53 üncü maddesinde belirtilen süreler geçmiş olsa bile; zimmet, irtikâp, rüşvet, hırsızlık, dolandirıcıllk, sahtecilik, güveni kötüye kullanma, hileli iflas, ihaleye fesat karıştırma, edimin ifasına fesat karıştırma, suçtan kaynaklanan mal varlı̆̆ değerlerini aklama ve kaçakçılık suçlarından birinden mahkûmiyeti bulunanlar sendika kurucusu olamaz."

denilerek sendika kurucusu olamayacak kişiler; "sendika üyeliği ve üyeliğin kazanılması" başliklı m.17'deyse

"On beş yaşını dolduran ve bu Kanun hükümlerine göre işçi sayılanlar, işçi sendikalarına üye olabilir."

denilerek sendikaya üye olabilecek kişiler gösterilmiştir. Bu nedenle suçun mağduru, sendika kurmak ve sendika üyesi olmak hakkı olan kişiler olabilir. ${ }^{15}$ Sendika kurmak, sendika üyesi olmak hakkı olmayan kişilerin bu yönde tehdit edilmeleri ya da cebredilmeleri halindeyse TCK m.118/1 değil, koşulları varsa tehdit (m.106) ya da kasten yaralamaya (m.86) ilişkin hükümler uygulanmalıdır.

Sendikaya üye olmak, işverenler açısından da söz konusu olabilir. İşverenin gerçek kişi olması halinde, işveren sendikasına üye olması ya da olmaması yönünde cebredilen ya da tehdit edilen söz konusu kişi suçun mağdurudur. İşverenin tüzel kişi olması da söz konusu olabilir. Bu durumda sendika tüzel kişiliğinin yanı sıra sendikanın üye olup olmamak yönünde karar verme yetkisine sahip olan ve bu yöndeki iradelerinin etkilenmesi amaciyla tehdit edilen ya da cebredilen gerçek kişilerin de suçun mağduru olduğu kabul edilmelidir.

\section{Suçun Maddi Unsuru: Sendikal Hakların Engellenmesi}

TCK m.118/f.1'de "Bir kimseye karşı bir sendikaya üye olmaya veya olmamaya, sendikanin faaliyetlerine katılmaya veya katılmamaya, sendikadan veya sendika yönetimindeki görevinden ayrlmaya zorlamak amaclyla, cebir veya tehdit kullanan kişi ... cezalandırılır."

denilmek suretiyle sendikal hakların kullanılmasının engellenmesini oluşturacak davranışlar sayılmıştır.

6356 say1lı Kanun'a göre (m.17/3);

"Sendikaya üye olmak serbesttir. Hiç kimse sendikaya üye olmaya veya olmamaya zorlanamaz."

Suç, sendika üyesi olmayan birinin sendikaya üye olmasını ya da sendikal faaliyetlere katılmasını sağlamak amacıyla tehdit edilmesi ya da cebredilmesi şeklinde işlenebileceği gibi sendikaya üye olmak isteyen kişinin fiilen engellenmesi şeklinde de işlenebilir. ${ }^{16}$

Kişilerin üyesi oldukları sendikaların her türlü faaliyetlerine katılmak hakkı bulunmaktadır. $\mathrm{Bu}$ hakkın engellenmesi halinde de suçun oluştuğunu kabul etmek gerekir. "Sendikal faaliyet" ayrıntıları 6356 sayılı Kanunla belirlenmiş olan, sendikaya üye olmak, ilgili mevzuatla belirlenen ve sendika tüzüğünde gösterilen sendikanın eğitim, kültür, iş ve çalışma ilişkilerine ilişkin toplantı, çalışma ve diğer etkinlikleridir. ${ }^{17}$ Sendika üyesi olan kişinin sendika üyeliğinden ayrılmaya, sendikanın faaliyetlerine katılmaya veya katılmamaya yönelik olarak zorlanması halinde de suç gerçekleşmiş olacaktır. ${ }^{18} \mathrm{Bu}$ niteliğinden dolayı, seçimlik hareketli bir suç söz konusudur. ${ }^{19}$ Sendika üyesi olmak, mutlaka sendika organlarında görev almak zorunluluğu doğurmaz. Bu nedenle, sendika üyesi olan kişinin sendika organlarında görev alması için cebredilmesi ya da tehdit edilmesi halinde de suçun gerçekleştiğini kabul etmek gerekir. ${ }^{20}$

Sendikalar esasen üyelerinin ortak ekonomik ve sosyal menfaatlerini korumak amaciyla kurulmuş olsalar da üyelerinin siyasal ve kültürel eğitimini amaçlayan diğer başka faaliyetleri de sendikal örgütlenme hakkı kapsamındadır. ${ }^{21} \mathrm{Bu}$ nedenle "sendikal faaliyet" ifadesi sendikanın bu yöndeki faaliyetlerini de kapsayacak biçimde geniş yorumlanmalıdır.

\footnotetext{
${ }^{15}$ Bkz. HAFIZOĞULLARI, Zeki/ÖZEN, Muharrem: Türk Ceza Hukuku Özel Hükümler, Kişilere Karşı Suçlar, US-A Yay., Ankara 2011, s.11.

${ }^{16}$ SOYER, s. 105.

${ }^{17}$ Bkz. ERSOY, s.493 vd.; EVIK, s.211.

${ }^{18}$ Bkz. EVIK, s.212.

19 BAYRAKTAR/KİİRIOĞLU/YILDIZ/ZAFER ve diğerleri, s.295; ARTUK, M. Emin/GÖKCEN, Ahmet/YENIDÜNYA, A. Caner: Ceza Hukuku Özel Hükümler, 7. Bask1, Turhan Kitabevi, Ankara 2006, s.275. Suçun, bağlı hareketli bir suç olduğu yönündeki görüş için bkz. ERSOY, s.488.

${ }^{20}$ Aksi görüşler için bkz. BAYRAKTAR/KIZİIİOĞLU/YILDIZ/ZAFER ve diğerleri, s.291-292.

${ }^{21}$ AYDIN, s.64-65.
} 
$\mathrm{Bu}$ hakkın kullanılmasının engellenmesi için kişinin mutlaka iradesine aykırı olarak sendikaya üye olması, sendika üyeliği ya da yöneticiliğinden ayrılmış olması gerekmez. Kişinin sendikal hakkını kullanmasını önlemek amacıyla tehdit edilmesi ya da cebredilmesi halinde suç tamamlanmış olacaktır. ${ }^{22}$ Kanunun gerekçesinde de;

"Bu suçun tamamlanmış şekline göre cezaya hükmedilebilmesi için, cebir veya tehdide maruz kalan kişinin sendikaya üye olması veya olmaktan vazgeçmesi, sendikanın faaliyetlerine katılması veya katılmaktan vazgeçmesi ya da sendikadan veya sendika yönetimindeki görevinden ayrlmasl gerekmemektedir. Bu amaçlarla, kişiye karşı cebir veya tehdit kullanılması, söz konusu suç tamamlanmış gibi cezalandırılabilmek için yeterlidir. Bu bakımdan söz konusu suç, bir teşebbüs suçu niteliği taşımaktadır."

şeklindeki açıklamayla suçun bu niteliği vurgulanmıştır. ${ }^{23} \mathrm{Bu}$ niteliğinden dolayı, tamamlanması öne alınmış bir suç, bir başka ifadeyle tehlike suçu söz konusudur. ${ }^{24}$

Kişilerin üyesi olmadıkları bir sendikanın toplantı, organizasyon ve diğer faaliyetlerine katılmalarının engellenmesi yönündeki davranışlar bu suçu oluşturmaz. Çünkü sendikaların bu tür faaliyetlerine katılmak hakkı esasen üyelere aittir. Aynı işyeri ya da aynı işkolunda faaliyet gösteren rakip sendika üyelerinin diğer sendika üyelerini kendi sendikal faaliyetlerine kabul etmek yükümlülüğü yoktur. Kişinin üyesi olmadığı bir sendikanın faaliyetine katılmak istemesinin tehditle ya da cebren engellenmesi halinde TCK m.118/1 değil, koşulları varsa tehdit ya da kasten yaralamaya ilişkin hükümler uygulanmalıdır. Çünkü sendikanın faaliyetlerine esasen üyeler katılabilirler. Üye olmayanların sendika faaliyetlerine katılmaları ancak sendikanın izniyle söz konusu olabilir.

Birinci fikradaki suçun varlığı için kişinin sendikal hakkının engellenmesi amacıyla cebredilmiş ya da tehdit edilmiş olması zorunludur. ${ }^{25}$

Tehdit; mağdurun hukuken korunan değerlerine yönelik, gerçekleşmesi failin iradesine bağl1 olan gelecekteki bir saldırı olasılığının bildirilmesidir. ${ }^{26}$ Tehdidin söz konusu olup olmadığı, TCK m.106'ya göre belirlenmelidir. TCK m.106' da tehdidin yöneldiği değerler suçun takibi ve ceza oranı açısından basamaklandırılmış olsa da bu suç yönünden tehditin yöneldiği hukuksal değerin bir önemi yoktur. Tehdit; mağdurun hayatına, beden tamlığına, malvarlığına, cinsel dokunulmazlığına, kişilik hakları, konut dokunulmazlığı gibi diğer haklarına yönelik olabilir. Tehdit, herhangi bir davranışla gerçekleştirilebilir. Sözlü, yazıll, görüntülü bir biçimde, bizzat fail ya da onun yönlendirdiği bir üçüncü kişi aracılığıyla da mağdurun tehdit edilmesi olanaklıdır. ${ }^{27}$ Tehdidin somut olayda objektif olarak ortalama bir insanı korkutmaya yeterli olması gerekir ancak mağdurun tehdidi ciddiye alıp almamasının, korkup korkmamasının önemi yoktur. ${ }^{28}$ İşçinin üyesi olduğu sendikadan istifa etmesi ya da sendikanın faaliyetlerine katılması ya da işaret edilen sendikaya üye olmaması halinde işten çıkarılmakla tehdit edilmesi halinde de sendikal faaliyetlerin engellenmesi suçu gerçekleşmiş olacaktır. ${ }^{29}$ Yargitay da

"Dava; sendikal hakların kullanılmasının engellenmesi suçuna ilişkindir. Oluş ve dosya kapsamına göre, mă̆durların üye olmalarının akabinde sanıklar tarafindan mă̆durların iş akitleri feshedilmek suretiyle işten çıkarıldıkları, mağdurların açmış oldukları işe iade davalarının, 'işyerinde başlatılan örgütlenme çalışmaları, davacının sendika üyeliği ile iş akdinin feshi arasında geçen süre, tanık beyanları dikkate alındiğında fesih nedeninin sendikal nedene dayalı olduğu' sebebiyle kabul edildiği, iddiaları doğrular nitelikteki tanık beyanları ve özellikle İ̧ Mahkemelerine ait kararların içeriği de göz önüne alındığında, sanıkların eylemlerinin TCK'nın 118/1. maddesi uyarınca sendikal hakların kullanılmasının engellenmesi suçunu oluşturduğu gözetilmelidir."

şeklindeki kararında bunu işaret etmiştir. ${ }^{30}$

${ }^{22}$ YARSUVAT, Duygun: "Yeni Türk Ceza Kanunu'nun 117 ve 118. Maddelerinde Yer Alan İş ve Çalışma Hürriyetinin İhlali, Sendikal Hakların Kullanılmasının Engellenmesi Suçları”, Sicil İş Hukuku Dergisi, (7), 2007, s.143.

23 Kanunun gerekçesi için bkz. Adalet Bakanlığı, 5237 sayılı Türk Ceza Kanunu tanıtım sayfası için bkz.

"http://www.ceza-bb.adalet.gov.tr."

${ }^{24}$ EVIIK, s. 10.

${ }^{25}$ Bkz. FINCAN, s.58.

${ }^{26}$ VIARO, Mario: "Violenza e Minaccia": Novissimo Digesto Italiano, Vol. XX, Milano 1976, s. 972; ANTOLISEI, Francesco: Manuale di Diritto Penale, Parte Speciale, (a cura di Luigi Conti), Vol.1, Milano 1986, s.125; ÖZBEK, Veli Özer/DOĞAN, Koray/Bacaksız, PINAR/TEPE, İlker: Türk Ceza Hukuku Özel Hükümler, 10.B., Seçkin Yay., Ankara, 2016, s. 392.

${ }^{27}$ ARTUK/GÖKCEN/YENIDÜNYA, s.215; ANTOLISEI, s.137.

${ }^{28}$ Bkz. AYDIN, Devrim: "Tehdit Suçu”: Ceza Hukuku Dergisi, (42), 2020, s.18.

${ }^{29}$ Bkz. YARSUVAT, Yeni Türk Ceza Kanunu'nun 117 ve 118. maddeleri, s.142-143.

${ }^{30}$ Yargitay 18. Ceza Dairesi'nin 26.02.2018 tarih ve 2016/2465 E., 2018/2453 K. Kazancı İçtihat Programı. 
Tehditten söz edilebilmesi için tehdit konusu kötülüğün gerçekleştirilmiş olması ya da tehdidin etkisiyle mağdurun sendikal hakkını kullanmaktan kaçınmış olması da gerekmez. ${ }^{31}$ Önemli olan tehdit oluşturan davranışın somut olayda ortalama bir insanı etkileyecek düzeyde olmasıdır. ${ }^{32}$ Yargitay;

"Sen stajyersin nasll böyle bir şeye cesaret edersin, stajyerlik işin nasll olacak, ... şu formu imzala, müdür vekilliğinden ya da üyelikten istifa edeceksin, istifanı bekliyorum."

şeklindeki sözlerin genç bir stajyer memur üzerinde tehdit oluşturacak düzeyde olmadığ yönündeki yerel mahkeme kararını hukuka aykırı bulmuştur. ${ }^{33}$ Yargıtay bir başka olayda da;

"İşçi olarak çalışmakta olan katılanın ... Sendikası'na üye olduğunu öğrenmeleri üzerine, 'sendikadan istifa et, yoksa seni işten atartz' diyerek tehdit etmek şeklinde iddia ve kabul olunan eylemlerinde TCY.nın 118. maddesinde tanımlanan "sendikal hakların kullanılmasinın engellenmesi" suçunun tehdit unsurunun oluştuğu gözetilmeden mahkumiyeti yerine yazılı şekilde beraatlerine karar verilmesi yasaya aykırıdır."

şeklinde yorumuyla işçinin sendikal haklarını kullanması halinde işten çıkarılacağı yönündeki sözlerin de tehdit olarak değerlendirilmesi gerektiği yönünde karar vermiştir. ${ }^{34}$

Cebir ise bir kişinin failin istediği belli bir şekilde davranışta bulunması amacıyla fiziken zorlanmasıdır. ${ }^{35}$ Failin cebir kullanmaktaki amacı, mağdurun direncini ortadan kaldırmak suretiyle sendikal haklarını kullanmasını önlemek olmalıdır. Örneğin sendika üyelik formunu doldurarak sendikaya üye olmak ya da sendikadan istifa dilekçesi yazmak isteyen failin darp edilmesi, kolunun bükülmesi, ellerine vurulması hallerinde suç gerçekleşmiş olacaktır. Failin cebir kullanmaktaki amacı, mağdurun sendikal faaliyette bulunmasını engellemek değil de bir başka amaçsa, bu durumda fail genel hüküm niteliğindeki cebir kullanma suçundan (TCK m.108) sorumlu olacaktır.

Cebir veya tehdit, doğrudan mağduru hedef alabileceği gibi mağdurun iradesine etki edebilmek amacıyla onun bir yakınana da yönelik olabilir. ${ }^{36}$ Suçun gerçekleşmesi için tehdit veya cebrin süreklilik göstermesi gerekmez, failin başlangıçtaki direncinin kırılması yeterlidir.

\section{Hukuka Uygunluk Nedenleri}

Bu suç açısından hukuka uygunluk nedenleri çok sınırlı biçimde gerçekleşebilir. ${ }^{37}$

Anayasa m.51/2 göre;

"Sendika kurma hakkı ancak, millî güvenlik, kamu düzeni, suç işlenmesinin önlenmesi, genel sağlık ve genel ahlâk ile başkalarının hak ve özgürlüklerinin korunması sebepleriyle ve kanunla sinurlanabilir."

Anayasa'daki bu ilgili hüküm ve 6356 sayılı Kanun'daki sınırlamalara aykırı bir faaliyet olması halinde bunu engellemek amacıyla verilmiş olan mahkeme hükmünü ya da idari emri uygulayan kamu görevlileri açısından TCK m.24/1'deki kanunun hükmünün, yetkili makamın emrinin yerine getirilmesi söz konusu olabilir. ${ }^{38}$

Hükümde geçen "kanun" ifadesinin hukuk kurallarını, mahkeme kararlarını ve düzenleyici işlemleri de içerecek biçimde geniş yorumlanması gerekir. ${ }^{39}$ Çünkü kanunun yanı sıra diğer hukuk kurallarını ve mahkeme kararlarını uygulayan kişiler açısından da hukuka uygunluk nedenleri söz konusudur. ${ }^{40}$ Örneğin özel bir kanunla sendika üyesi olmasına izin verilmeyen kişinin işyerinde

\footnotetext{
${ }^{31}$ Bkz. ERSOY, s.496.

${ }^{32}$ VIARO, s.973; ANTOLISEI, s.137.

${ }^{33}$ Yargıtay 18. Ceza Dairesi'nin 04.7.2018 tarih ve 2016/11648 E., 2018/10716 K. sayılı kararı için bkz. Kazancı İçtihat Program1.

${ }^{34}$ Yargıtay 4. Ceza Dairesi’nin 14.7.2010 tarih ve 2008/15172 E., 2010/13889 K. sayılı kararı için bkz. Kazancı İçtihat Programi.

35 ANTOLISEI, s.127; ÜZÜLMEZ, İlhan: Tehdit, Şantaj ve Cebir Kullanma Suçları, Turhan Kitabevi, Ankara 2007, s.89; ÖZBEK/DOĞAN/BACAKSIZ/TEPE, s.412.

${ }^{36}$ EVIK, s.208; ERDOĞAN, s.79.

${ }^{37}$ Birinci fikrada yer alan sendikal hakların kullanılmasının engellenmesi suçu açısından hakkın kullanılması ve ilgilinin kullanılmasının söz konusu olabileceği yönündeki görüş için bkz. ERSOY, s.497.

${ }^{38}$ Amirin ve yetkili makamın emrinin hukuka uygunluk nedeni mi yoksa kusurluluğa etki eden neden mi olduğu öğretide tartışmalıdır. Bir görüşe göre, emri yerine getirenin içinde bulunduğu hiyerarşik yapı nedeniyle emrin yerine getirilmesi kusurluluğa etki eden neden olarak kabul edilmelidir. Diğer görüşe göreyse, amirler tarafından verilen hukuka uygun emirlerin yerine getirilmesi kamu hukuku ve idare hukukunun gereği olduğundan, hukuka uygunluk nedenidir. Bu yöndeki tartışmalar hakkında bkz. ZAFER, Hamide: Ceza Hukuku Genel Hükümler, Beta Yay., İstanbul, 2021, s.392 vd.; TOROSLU, Nevzat/TOROSLU, Haluk: Ceza Hukuku Genel Kısım, Savaş Yay., Ankara 2015, s.151 vd. Çalışmada, yetkili makamın emrinin yerine getirilmesinin hukuka uygunluk nedeni olduğu yönündeki görüşler esas alınmıştır.

${ }^{39} \mathrm{Bkz}$. TOROSLU/TOROSLU, s.152.

${ }^{40}$ Bkz. TOROSLU/TOROSLU, s. 152.
} 
sendikal faaaliyet yürütmesine engel olunması halinde, fail bu hukuka uygunluk nedeninden yararlanabilecektir. Ancak sendikal hakkın kullanılmasını engellemeye yönelik olarak verilen ve konusu hukuka aykırı olan ya da içeriği suç oluşturan emirlerin yerine getirilmesi halinde hukuka uygunluk nedeni söz konusu değildir. Sendika tüzüğüne aykırı davranan üye hakkında yürütülen disiplin soruşturması sonunda kimi sendikal faaliyetlere katılmanın kısıtlanması ya da üyelikten çıkarmak şeklinde bir yaptırım uygulanması söz konusu olabilir. Disiplin soruşturması boyunca tedbiren sendikal faaliyetlere katılması engellenen ya da hakkında yaptırım uygulanan üyenin faaliyetlere katılmasının engellenmesi de sendika açısından TCK m.24/1'deki kanunun hükmünü yerine getirmek kapsamında değerlendirilmelidir.

\section{E. Suçun Manevi Unsuru}

$\mathrm{Bu}$ suç kasten işlenebilen suçlardandır. Mağdurun sendikaya üye olmaya veya olmamaya, sendikanın faaliyetlerine katılmaya veya katılmamaya, sendikadan veya sendika yönetimindeki görevinden ayrılmaya zorlanması amacıyla cebir veya tehdit kullanılması arandığından, failin özel kasıtla hareket etmesi gerekir. ${ }^{41} \mathrm{Bu}$ nedenle failin uyguladığı cebir ya da tehdidin amacı mağdurun sendikal haklarının kullanılmasına yönelik değilse bu suçtan söz edilemez. Örneğin fail sendika binasında bulunan mağduru sendikal haklarını engellemek amacıyla değil de bir başka nedenle tehdit etmişse genel nitelikteki TCK m.106'ya göre sorumlu olacaktır. Bu suç özel kasıtla işlenebildiğinden, suçun olası kasıtla işlenmesi söz konusu değildir.

\section{F. Kusurluluğa Etki Eden Nedenler}

$\mathrm{Bu}$ suç yönünden kusurluluğa etki eden bir nedenin söz konusu olması oldukça güçtür. Mağdurun katılmasının engellendiği faaliyetin sendikal faaliyet olup olmadığı konusunda hata edilmesi durumunda, esaslı bir hata olmadığı için fail TCK m.118/1'e göre sorumlu olmasa da genel hükümlere göre sorumlu olacaktır. Şahısta hata edilmesi söz konusu olsa da esaslı bir hata olmadığından failin ceza sorumluluğuna etki etmez. Örneğin sendikadan istifa etmesini sağlamak için karanlıkta (A) zannedilerek (B) cebredilmiş olsa da fail TCK m.118/1'e göre sorumlu olacaktır. Çok sınırlı biçimde de olsa bu suçun haksız tahrikin etkisiyle işlenmesi söz konusu olabilir. Örneğin fail kendisine hakaret eden ya da aldığı borcu ödemeyen iş arkadaşının bu davranışına öfkelenerek üye oldukları sendikadan istifa etmesi için tehdit ettiğinde olayda haksız tahrikin uygulanması söz konusu olabilir.

\section{G. Suçun Ortaya Çıkış Biçimleri \\ 1. Teşebbüs}

Sendikal hakların kullanılmasının engellenmesi için kişinin hukuka aykırı olarak sendikaya üye olması, sendika üyeliğinden ya da yöneticiliğinden ayrılmış olması gerekmez. Kişinin bu konudaki iradesinin hukuka aykırı olarak etkilenmeye çalışılmasıyla suç tamamlanmış olacaktır. Mağdurun sendikaya üye olmak, üye olmamak, yöneticilik görevinden ayrılıp ayrılmamak yönündeki iradesinin engellenmesine yönelik hareketlerin bitirilememiş olması halindeyse suçun teşebbüs aşamasında kaldığını kabul etmek gerekir. ${ }^{42}$ Örneğin mağdurun istifa etmesini sağlamak amacıyla yazılan tehdit mektubu muhatabına ulaşmadığında, suça teşebbüs söz konusu olacaktır.

\section{2. İştirak}

Bu suç, iştirak hükümleri açısından herhangi bir özellik göstermez. İştirakin bütün türleri gerçekleşebilir. Failin ikna edilerek azmettirilmesi ve yardım etmenin bütün türleri olanaklıdır. Sınırlı biçimde de olsa sendikal hakların kullanılmasının engellenmesini sağlamak amacıyla bir başka kişinin cebredilmesi, hataya düşürülmesi, isnat yeteneği olmayan kişinin araç olarak kullanılması da söz konusu olabilir. Bu durumda mağdurun sendikal haklarını engelleyen kişi değil, faili arka planda yönlendiren kişi dolaylı faillik hükümlerine göre sorumlu olacaktır.

\section{H. İçtima}

Sendikal hakların kullanılmasının engellenmesi suçu, sendikaya üye olmaya veya olmamaya, sendikanın faaliyetlerine katılmaya veya katılmamaya, sendikadan veya sendika yönetimindeki görevinden ayrılmaya zorlamak amacıyla mağdura karşı cebir veya tehdit kullanılmasıdır. Cebir veya tehdidin kullanılmasının suçun maddi unsuru olduğu yukarıda ele alınmıştı. Bu nedenle sendikal hakların kullanılmasının engellenmesi suçu bileşik (mürekkep) suçtur. Dolayısıyla bu suçun unsurunu oluşturan cebir veya tehdit suçlarından dolayı faile ayrıca ceza verilmez (TCK m.42).

41 HAFIZOĞULLARI/ÖZEN, s.212; BAYRAKTAR/KİZIRİĞGLU/YILDIZ/ZAFER ve diğerleri, s.301-302; YARSUVAT, Yeni Türk Ceza Kanunu'nun 117 ve 118. maddeleri, s.143.

${ }^{42}$ Bkz. EVIK, s.211. 
Sendikal hakların kullanılmasının engellenmesi suçunun zincirleme suç biçiminde işlenmesi de söz konusu olabilir. Tek bir suç işleme kararı kapsamında aynı kişiye karşı sendikal hakkının kullanılmasının engellenmesi amacıyla değişik zamanlarda tehdit ya da cebir uygulanması halinde fail hakkında bir cezaya hükmedilerek cezanın artırılması yoluna gidilmelidir (TCK m.43/1). ${ }^{43}$ Ancak bunun için cebir ya da tehdit oluşturan davaranışların farklı zamanlarda gerçekleştirilmiş olması gerekir. Örneğin mağdura bu amaçla birkaç hafta arayla tehdit mesajı gönderilmesi ya da mağdurun cebredilmesi halinde olaya zincirleme suç hükümleri uygulanmalıdır. Mağdura sendikadan istifa etmesi için bir saat gibi kısa bir süre zarfında birkaç tehdit mesajı gönderildiğindeyse zincirleme suç hükümleri uygulanmamalıdır çünkü bu durumda tehdit oluşturan davranışlar aynı suçun parçaları niteliğindedir.

Öte yandan failin birden fazla kişiyi tehdit ederek sendikal haklarının kullanmalarını engellemesi halinde de olaya zincirleme suç hükümleri uygulanabilir. Örneğin sendika genel kurulunun yapıldığg salonun girişinde elindeki bıçakla kapıda bekleyerek bir grup muhalif üyenin oy kullanmasını engelleyen fail aynı suçu birden fazla kişiye karşı tek bir fiille işlemiş olduğundan (TCK m 43/2) olaya zincirleme suç hükümleri uygulanacaktır. Aynı suçun birden fazla kişiye karşı tek bir fiille işlenmesi söz konusu olacağından, bu durumunda da fail hakkında TCK m.43/1 uygulanarak bir cezaya hükmedilerek ceza bir miktar arttılacaktır.

Cebre başvurularak mağdurun sendikal hakkını kullanmaya yönelik başlangıçtaki direncinin kırılması yeterlidir. Tehdit ya da cebrin süreklilik göstermesi gerekmez. Uygulanan cebrin ağırlaşmış yaralamaya neden olması halinde fail ağırlaşmış yaralamadan dolayı sorumlu olacaktır. ${ }^{44}$

Sendikal hakların kullanılmasının engellenmesi amacıyla diğer başka suçların işlenmesi de söz konusu olabilir. Bu durumda gerçek içtima söz konusu olacaktır. Örneğin muhalif üyelerin oylamaya katılmasının ya da sendikadan istifa etmek için dilekçe vermelerinin engellenmesi amacıyla bir odaya kapatılmaları halinde TCK m.118/1'deki suçun yanı sıra hürriyeti sınırlama suçu (m.109) da gerçekleşmiş olacaktır.

\section{SENDİKANIN FAALIYETININ ENGELLENMESİ (TCK m.118/2)}

\section{A. Suçun Hukuki Konusu}

TCK m.118/2'de;

"Cebir veya tehdit kullanılarak ya da hukuka aykırı başka bir davranışla bir sendikanın faaliyetlerinin engellenmesi halinde, bir yıldan üç ylla kadar hapis cezasina hükmolunur."

şeklindeki düzenlemeyle sendika tüzel kişiliğinin faaliyetlerinin ceza hukuku yoluyla korunması amaçlanmıştır. Bu suçun hukuki konusu, sendika tüzel kişiliğinin uluslararası sözleşmeler, Anayasa ve ilgili mevzuat tarafindan korunan sendikal faaliyette bulunabilmesine ilişkin kamusal yarardır. ${ }^{45}$ Kanun metninde sendika kurmaktan ve konfederasyondan söz edilmediği için madde metninin bu özgürlükleri de açıkça koruyacak biçimde değiştirilmesi gerektiği ileri sürülmüş̧ür. ${ }^{46}$ Sendikalar, konfederasyon bünyesinde örgütlenebildiklerinden, kanun metninde açıkça gösterilmiş olmasa da bu hükümle konfederasyonlarının faaliyetlerinin de korunduğu kabul edilmelidir.

\section{B. Suçun Faili, Mağduru, Maddi Konusu}

$\mathrm{Bu}$ suçun faili herhangi bir gerçek kişi olabilir. Fail, ilgili sendikanın üyesi olan kişiler de olabilir. Suçun mağduru ise sendika tüzel kişiliğidir. ${ }^{47}$ Suçun, konfederasyonun faaliyetlerinin engellenmesi amacıyla işlenmesi halindeyse sendika üst kuruluşu olan konfederasyon mağdurdur. ${ }^{48}$ Sendika üyesi olan gerçek kişiler, bu suç nedeniyle suçtan zarar gören kişilerdir. Bir başka görüşe göre, sendika tüzel kişiliği bu suç nedeniyle suçtan zarar gören, sendika yöneticileri, sendika işyeri temsilcileri ve kendilerine karşı cebir kullanılan ya da tehdit edilen gerçek kişiler ise suçun mağdurudur. ${ }^{49}$ CMK m.237/1'e göre suçun mağdurunun yanı sıra suçtan zarar gören de kamu davasına katılma hakkına sahiptir. Katılanın haklarının düzenlendiği CMK m.239'da ise katılanın suçtan zarar gören ya da mağdur olması yönünden bir ayrıma gidilmemiştir. Görüldüğü üzere suç

\footnotetext{
${ }^{43}$ ERDOĞAN, s.89.

${ }^{44}$ Bkz. BAYRAKTAR/KIZİIIOĞLU/YILDIZ/ZAFER ve diğerleri, s.292.

45 HAFIZOĞULLARI/ÖZEN， s.212; BAYRAKTAR/KIZİIIOĞLU/YILDIZ/ZAFER ve diğerleri， s.286-287; FINCAN, s.49.

${ }^{46}$ Bkz. ERDOĞAN, s.71. Kanun metninde konfederasyondan söz edilmediği için, konfederasyonların faaliyetinin engellenmesinin suç olmayacağ1 yönündeki görüş için bkz. ERSOY, s.502; ERDOĞAN, s.72; SOYER, s.101; ÜZÜLMEZ, s.109.

${ }^{47}$ ERDOĞAN, s.76.

${ }^{48}$ Bkz. BAYRAKTAR/KIZİİOĞLU/YILDIZ/ZAFER ve diğerleri, s.290; SOYER, s. 102.

${ }^{49}$ BAYRAKTAR/KİİRİĞLU/YILDIZ/ZAFER ve diğerleri, s.288; SOYER, s.102.
} 
genel teorisi açısından yapılan mağdur ve suçtan zarar gören ayrımının bu suç yönünden ceza yargılaması pratiğinde bir önemi yoktur.

Bu suçun maddi konusu, kendisine karşı tehdit uygulanan ya da cebredilen gerçek kişidir. ${ }^{50}$

\section{Suçun Maddi Unsuru: Sendika Faaliyetlerinin Engellenmesi}

TCK m.118/'de yer alan;

"Cebir veya tehdit kullanılarak ya da hukuka aykırı başka bir davranışla bir sendikanın faaliyetlerinin engellenmesi ..."

şeklindeki düzenlemeye göre, sendikanın faaliyetinin cebir veya tehditle ya da hukuka aykırı bir başka davranışla engellenmesi halinde suç tamamlanmış olacaktır. Suçun gerçekleşmesi için, yapılan müdahalelerin neticesinde sendikanın ilgili mevzuatta belirlenmiş olan faaliyetlerini yapmasına fiilen etki edilmiş olmalıdır. Kanunun gerekçesinde de;

"Maddenin ikinci fikrasında cebir veya tehdit kullanılarak ya da hukuka aykırı başka bir davranışla bir sendikanın faaliyetlerinin engellenmesi ayrı bir suç olarak tanımlanmıştır. Bir sendikanın faaliyetlerinin cebir veya tehditle ya da hukuka aykırı başka bir davranışla engellenmiş olması hâlinde, suç tamamlanmış olur."

şeklindeki açıklamayla bu duruma işaret edilmiştir. ${ }^{51}$ Suçun tamamlanması için sendikanın faaliyetlerinin tamamen ortadan kaldırılmış olması gerekmez. Sendikal faaliyetlerin kısmen engellenmiş olması, ilgili mevzuatın belirlediği hakların ihlal edilmiş olması yeterlidir. ${ }^{52}$ Sendika afişlerinin asılmasının önlenmesi, sendika binasının kullanılmasının önlenmesi için elektriklerin kesilmesi, binaya girişlerin engellenmesi, sendikanın üyelerine yönelik eğitimlerinin ve yeni üye kazanma çalışmalarının engellenmesi gibi hallerde suç gerçekleşmiş olacaktır. Suçun varlığı için sendikanın faaliyetlerinin belirsiz veya çok uzun süreli olarak önlenmiş olması gerekmez. Örneğin işyerindeki sendika afişlerinin zorla indirilmesi halinde suç tamamlanmış olacaktır.

Engellemek seklindeki davranışlar icrai nitelikte olabileceği gibi ihmali nitelikte de olabilir. ${ }^{53}$ Örneğin binanın elektriklerinin kesilmesi icrai nitelikteyken, sendika binasında yapılması planlanan toplantıların aksatılması amacıyla elektrik idaresinin elektrik arızasını gidermemesi, ilgili kamu kurumlarının sendika aidatlarının sendikaya ödenmesini geciktirmesi şeklinde ihmali davranışla işlenmesi de söz konusu olabilir. Engellemek, herhangi bir davranışla gerçekleştirilebileceğinden, serbest hareketli bir suç söz konusudur. ${ }^{54}$

$\mathrm{Bu}$ suç, ani nitelikte bir suç olup engelleme ya da ihlalin gerçekleştiği anda suç da tamamlanmış olacaktır. ${ }^{55}$ Suçun gerçekleşmesi için sendikanın faaliyetlerinin belirli bir süre için engellenmiş olması gerektiğinden 1. fikradaki suçtan farklı olarak buradaki suç zarar suçudur. ${ }^{56}$ Sendikal faaliyetlerin engellenmesinin zorunlu olarak süreklilik göstermesi gerekmez, ancak birçok durumda engellemenin belirli bir süre devam etmesi söz konusu olabilir. ${ }^{57}$

Engellemenin cebir ya da tehditle gerçekleştirildiğinin kabul edilebilmesi için failin davranışlarının TCK m.106 ve 108 'e göre değerlendirildiğinde tehdit ya da cebir oluşturması gerekir. Ancak engellemenin hukuka aykırı davranışlarla gerçekleştirilmesinin neyi ifade ettiği konusunda açıklı yoktur. ${ }^{58}$ Bir görüşe göre, hukuka aykırı başka bir davranış ifadesi "hileli davranışlar" olarak anlaşılmalıdır. ${ }^{99}$ Ancak bir davranışın hukuka aykırı olması için mutlaka hileli davranış olması gerekmez. Bu görüş sahipleri, idarenin hukuka aykırı işleminin sonucu olarak sendikanın faaliyetlerinin engellenmesi halinde bu suçun söz konusu olmayacağını, söz konusu idari işlemi tesis eden ilgili kamu görevlileri açısından görevi kötüye kullanmaktan bahsedileceğini savunmaktadırlar. ${ }^{60}$

Hukuka aykırı başka bir davranış ifadesi, tehdit ve cebir niteliğinde olmayan hukuka aykırı bütün davranışları içerebilir. Bu davranışların mutlaka suç olması gerekmez. Bu nedenle hileli davranışların yanı sıra sendikanın faaliyetlerinin önlenmesi amacıyla kamusal yükümlülüklerin

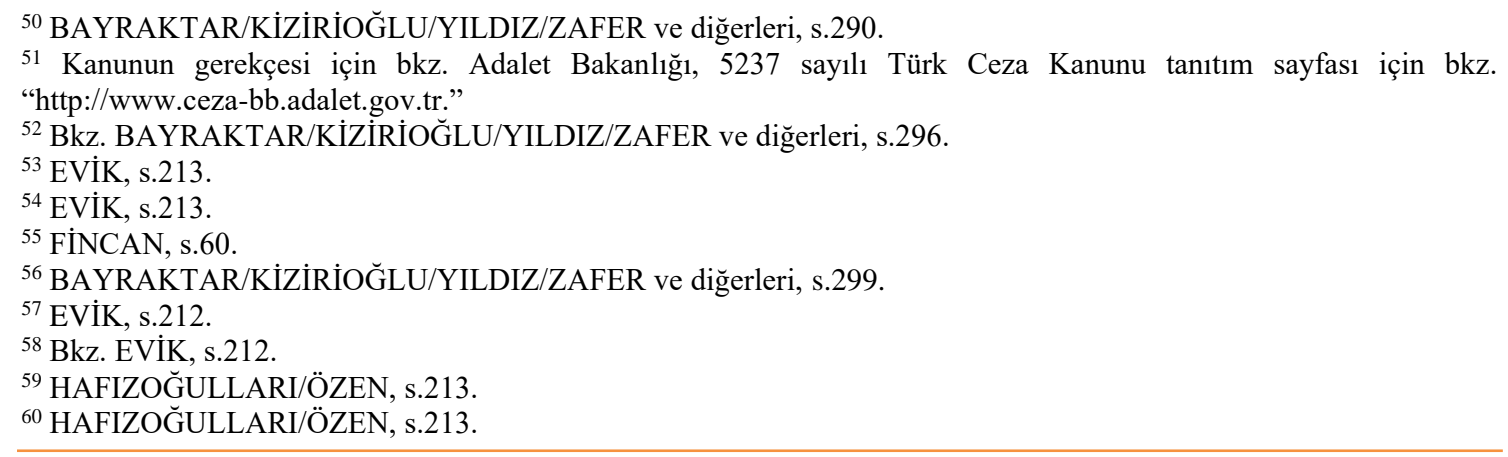


aksatılması, üyelerin istifa etmesini sağlamak için iş ve sendika hukukuna aykırı yararlar vaad edilmesi söz konusu olabilir. Örneğin bir sendikaya yapılacak tebligatın sendikal faaliyeti engellemek amacıyla bilinçli olarak geciktirilmesi ya da sendika toplantılarının hukuki dayanağ olmayan gerekçelerle mülki amir tarafından ertelenmesi hileli davranış olmasa da hukuka aykırı niteliktedir.

Sendika faaliyetlerinin kamu görevlileri tarafından içeriği hukuka aykırı ya da konusu suç teşkil eden emirleri uygulamaları suretiyle engellenmesi de söz konusu olabilir.

Anayasa'nın "Kanunsuz emir" kenar başl1klı 137. maddesine göre;

"Kamu hizmetlerinde herhangi bir sifat ve suretle çalışmakta olan kimse, üstünden aldĭg emri, yönetmelik, Cumhurbaşkanlığ kararnamesi, kanun veya Anayasa hükümlerine aykırı görürse, yerine getirmez ve bu aykirlliğl o emri verene bildirir. Ancak, üstü emrinde ısrar edeve bu emrini yazı ile yenilerse, emir yerine getirilir; bu halde, emri yerine getiren sorumlu olmaz.

Konusu suç teşkil eden emir, hiçbir suretle yerine getirilmez; yerine getiren kimse sorumluluktan kurtulamaz."

"Kanunun hükmü ve amirin emri” başlıklı TCK m.24/3'e göreyse;

"Konusu suç teşkil eden emir hiçbir surette yerine getirilemez. Aksi takdirde yerine getiren ile emri veren sorumlu olur."

$\mathrm{Bu}$ düzenlemelere göre, içeriği hukuka aykırı emri uygulayan memur sorumlu olmaz ancak emri veren sorumlu olur. İçeriği suç olan emri veren amirin yanı sıra bu emri uygulayan memur da özel hüküm olan TCK m.118/2'ye göre sorumlu olacaktır. Görüldüğü üzere, sendika faaliyetlerinin "hukuka aykırı başka davranışlarla" kamu görevlileri tarafından engellendiğinin iddia edilmesi halinde emrin içeriğinin suç olup olmadığı gibi konuların da belirlenmesi gerekecektir.

\section{Hukuka Uygunluk Nedenleri}

$\mathrm{Bu}$ suç açısından gerçekleşebilecek olan hukuka uygunluk nedenleri, TCK m.24'te düzenlenmiş olan kanunun ve yetkili makamın emrinin uygulanması olabilir. ${ }^{61}$ Yukarıda açıklandığı gibi, hükümde geçen "kanun" ifadesinin hukuk kuralları, mahkeme kararları ve düzenleyici işlemleri de içerecek biçimde geniş yorumlanması gerekir. Örneğin, sendika kurulmasına izin verilmeyen bir işkolunda örgütlenmek için işyerine afişler asarak sendikal faaaliyet yürütmek isteyen sendikanın afişlerinin indirilmesi emrini veren amir ve bu afişleri indiren memurlar, kanunun emrini uyguladıkları için sorumlu olmazlar. Çünkü ortada, kanunlara uygun olarak kurulmuş bir sendika bulunmamaktadır.

Öte yandan çok sınırlı biçimde de olsa sendikal faaliyetlerin zorunluluk hali nedeniyle engellenmesi söz konusu olabilir. Örneğin, sendika genel kurulunun yapılacağı binanın yıkılma tehlikesi içinde olması nedeniyle girişlerin engellenmesi, salgın hastalık nedeniyle sendika toplantılarının yapılmasına idari kararla izin verilmemesi hallerinde ilgili kişiler zorunluluk halinden yararlanabilirler. ${ }^{62}$

\section{E. Suçun Manevi Unsuru}

$\mathrm{Bu}$ suç ancak kasten işlenebilen bir suçtur. Failin bilerek ve isteyerek bir sendikanın faaliyetini engellemeye yönelik davranışları, suçun oluşması için yeterlidir. ${ }^{63}$ Bu fikradaki suç açısından failin genel kasıtla hareket etmesi yeterlidir, özel kasıt aranmaz. Sınırlı biçimde de olsa suçun olası kasıtla işlenmesi olanaklıdır. ${ }^{64}$

\footnotetext{
${ }^{61}$ Bkz. ERSOY, s.506-507.

${ }^{62}$ Türk Ceza Kanunu ile Ceza Muhakemesi Kanunu'ndaki düzenlemeler nedeniyle zorunluluk halinin hukuka uygunluk nedeni mi yoksa kusurluluğa etki eden neden mi olduğu yönünde farklı fikirler bulunmaktadır. "Meşru savunma ve zorunluluk hali" başlıklı TCK m.25/2'ye göre, "Gerek kendisine gerek başkasına ait bir hakka yönelik olup, bilerek neden olmadığı ve başka suretle korunmak olanağı bulunmayan ağır ve muhakkak bir tehlikeden kurtulmak veya başkasını kurtarmak zorunluluğu ile ve tehlikenin ağırlığı ile konu ve kullanılan vasıta arasında orantı bulunmak koşulu ile işlenen fiillerden dolayı faile ceza verilmez." CMK m.223/3, b'ye göreyse "Yüklenen suçun ... zorunluluk hali etkisiyle işlenmesi halinde ... ceza verilmesine yer olmadığı kararı” verilir. TCK ve CMK'da zorunluluk hali konusundaki bu farklı düzenlemeler TCK hazırlanırken etkisinde kalınan Alman Ceza Kanunu'nun zorunluluk hali ile ilgili farklı düzenlemelere gitmiş olmasından kaynaklanmaktadır. Alman Ceza Kanunu m.34'te "Rechtfertigender Notstand" başlığı altında "hukuka aykırılığı kaldıran" zorunluluk nedenine yer verilmişken, m.35'te "Entschuldigender Notstand" başlığı altında "kusurluluğu ortadan kaldıran" zorunluluk nedeni düzenlenmiştir. Ancak TCK bunlardan hukuka aykırılığı ortadan kaldıran tanımı esas almış olmasına rağmen CMK'da zorunluluk hali, kusurluluğu ortadan kaldıran bir neden olarak kabul edilmiştir. Çalışmada, zorunluluk halini hukuka uygunluk nedenleri arasında değerlendiren görüşler esas alınmıştır. Bkz. VINCIGUERRA, Sergio: il Codice Penale Tedesco, CEDAM, Padova 2003, s.63; ZAFER, s.406 vd.

${ }^{63}$ HAFIZOĞULLARI/ÖZEN, s.213.

${ }^{64}$ Bkz. ÖZEN, s.65.
} 
Sendikal faaliyetin engellenmesi kesintisiz (mütemadi) bir suç değildir. Ancak önemsiz kimi davranışlar, oldukça kısa süreli ve geçici engellemeler halinde suç söz konusu olmaz. Örneğin sendika genel kurulunun yapılacağı sendika binasının giriş kapısının toplantıyı engellemek amacıyla uzun süre kilitlenmesi, binanın elektrik ve suyunun bu amaçla kesilmesi halinde suçun gerçekleştiği kabul edilebilirse de binaya girişlerin engellenmesi için kısa bir süre kapının kilitlenmesi halinde suçun teşebbüs aşamasında kaldığını kabul etmek gerekir.

\section{F. Kusurluluğa Etki Eden Nedenler}

Birinci fikrada olduğu gibi, bu fikradaki suç yönünden de kusurluluğa etki eden bir nedenin söz konusu olması oldukça güçtür. Çok sınırlı biçimde de olsa bu suç açısından kusurluluğu kaldıran esaslı hata söz konusu olabilir. ${ }^{65}$ Örneğin, verilen bir idari emrin içeriğini yanlış yorumlayarak sendikanın faaliyetini engelleyen kamu görevlisi hata hükümlerinden yararlanabilmelidir.

$\mathrm{Bu}$ suçun mağduru sendika tüzel kişiliği olduğundan, suçun haksız tahrikin etkisiyle işlenmesi söz konusu olamaz. Gerçek kişinin tahrik oluşturan haksız hareketine tepki olarak sendikanın faaliyetinin engellenmesi halinde tepki üçüncü bir kişiye yöneltilmiş olacağından, fail tahrik indiriminden yararlanamaz. Örneğin fail, kendisini döven sendika yöneticisinin bu fiiline tepki olarak sendikanın faaliyetini engellediğinde haksız tahrik indirimi söz konusu olmaz.

\section{G. Suçun Ortaya Çıkış Biçimleri}

\section{Teşebbüs}

$\mathrm{Bu}$ suç cebir, tehdit ya da hukuka aykırı davranışla sendikanın faaliyetinin engellendiği anda tamamlanmış olur. Kanunda, suçun tamamlanması için sendika faaliyetlerinin engellenmiş olması koşulu aranmaktadır. Sendikanın faaliyetinin engellenmesi zarar suçu niteliğinde olduğundan ve sendikal faaliyetlerin engellenmesinin icra hareketleri parçalara bölünebileceğinden, sinırlı biçimde de olsa bu suça teşebbüs mümkündür. ${ }^{66}$ Örneğin üyeleri tehdit ederek sendika genel kurulunun yapılmasını engellemek amacıyla genel kurulun yapılacağı salonun önünde elindeki sopayla beklerken durumu fark eden kolluk tarafından yakalanana failin davranışının teşebbüs aşamasında kaldığı kabul edilmelidir.

\section{2. İştirak}

Birinci fikrada olduğu gibi bu suç açısından da azmettirmek ya da yardım etmek suretiyle suça iştirak söz konusu olabilir. Sendikanın faaliyetinin engellenmesini sağlamak amacıyla bir kişinin cebredilmesi, kusur yeteneği olmayan kişinin bu suçu işlemesi için araç olarak kullanılması halindeyse arka plandaki kişi, dolaylı fail olarak sorumlu olacaktır.

\section{H. İçtima}

Sendikanın faaliyetinin engellenmesinin zincirleme biçimde işlenmesi çok sınırlı biçimde söz konusu olabilir. Tek bir suç işleme kararı kapsamında aynı sendikanın faaliyetlerinin değişik zamanlarda engellenmesi halinde, fail hakkında bir cezaya hükmedilerek cezanın artırılması yoluna gidilmelidir. Tek bir suç işleme kararı kapsamında sendikanın farklı şubelerindeki faaliyetlerin değişik zamanlarda önlenmesi halinde de aynı sonuca varmak gerekir.

2. fikradaki suç kolektif sendikal hakları ihlal ettiğinden, üyelerin bireysel sendikal hakları da dolaylı olarak ihlal edilmektedir. Bu nedenle sendikanın faaliyetlerini ihlal eden failin aynı zamanda birinci fikradaki sendikal hakların kullanılmasından da sorumlu olacağı, bu nedenle failin fikri içtima hükümleri uygulanarak en ağır ağır ceza gerektiren 2. fikra hükmüne göre sorumlu olmasi gerektiği ileri sürülmüştür. ${ }^{67}$ Ancak 2 . fikradaki suçtan sorumlu olan fail hakkında fikri içtima hükümlerinin uygulanarak yine bu fikrada öngörülen ceza nedeniyle sorumlu olduğunu söylemenin pratikte bir değeri yoktur.

\section{SUÇUN NITELİKLİ HALLERI VE SUÇ İŞLENIRKEN BAŞVURULAN CEBRIN AĞIRLAŞMIŞ YARALAMAYA NEDEN OLMASI}

TCK m.118'de yer alan her iki suç açısından ağırlatıcı ya da hafifletici nedene yer verilmemiştir. Hürriyete karşı suçlar açısından ortak hüküm olan TCK m.119'daki ağırlatıc1 nedenlerin uygulanacağ 1 suçlar ise sayma yöntemiyle belirlenmiş olup, bunlar arasında sendikal hakların kullanılmasının engellenmesi suçu yer almamaktadır. TCK m.119'da sayılanlar suçlar arasında bu suçun olmamasının nedeni olarak, sendikal hakların engellenmesi suçunun TCK metnine ortak hükümle Adalet alt komisyonunda değil de sonradan, Adalet Komisyonu'nda

\footnotetext{
${ }^{65}$ HAFIZOĞULLARI/ÖZEN, s.213.

${ }^{66}$ Aksi yöndeki görüș için bkz. SOYER, s.107.

${ }^{67}$ BAYRAKTAR/KİŻंIIOĞLU/YILDIZ/ZAFER ve diğerleri, s.304; EVIK, s.215.
} 
eklenmiş olması gösterilmektedir. ${ }^{68}$ Kanunilik ilkesi gereğince TCK m.119'da sayılan nitelikli hallerin TCK m.118'deki suçlar açısından uygulanması yoluna gidilemez. Bu nedenle, TCK m.119'da sayılan suçlar arasına sendikal hakların kullanılmasının engellenmesi suçunun eklenmesi doğru olacaktır. ${ }^{69}$

Hürriyete karşı suçlarla ilgili olarak ağırlatıcı nedenlerin düzenlendiği "Ortak hüküm” kenar başlıklı TCK m.119/2'de gerçek içtima hükmüne yer verilmiştir. Buna göre, birinci fikrada sayılan suçların işlenmesi sırasında kasten yaralama suçunun neticesi sebebiyle ağırlaşmış hallerinin gerçekleşmesi durumunda, ayrıca kasten yaralama suçuna ilişkin hükümler uygulanacaktır. Ancak yukarıda belirtildiği üzere, sendikal hakların kullanılmasının engellenmesi suçu TCK m.119/1'de sayılmamıştır. Buna rağmen, sendikal hakların kullanılmasının engellenmesi amacıyla başvurulan cebrin, kasten yaralama sınırlarını aşmaması gerekir. Cebrin, neticesi sebebiyle ağırlaşmış yaralamaya neden olması durumunda, failin hem TCK m.118'deki suçtan hem de ağırlaşmış yaralamadan dolayı sorumlu olması ve gerçek içtimaya gidilmesi konusunda tereddüt edilmemelidir. $^{70}$

Cebir ya da tehdit doğrudan mağdura yöneltilebileceği gibi onu korkutmak amaciyla üçüncü bir kişiye de yöneltilebilir. Örneğin fail, mağdurun sendikadan istifa etmesini sağlamak amaciyla onu darp edebileceği gibi mağdurun bir yakınını da bu amaçla darp edebilir. Bu durumda fail sendikal hakların kullanılmasının engellenmesinin yanı sıra cebrettiği kişi yönünden de kasten yaralama hükümlerine göre sorumlu olacaktır.

\section{SUCUN MUHAKEMESİ VE YAPTIRIMI}

Her iki suç da re'sen soruşturulan suçlardandır. Bu nedenle suçun mağduru olan gerçek kişinin ya da sendikanın şikâyetçi olup olmamasının suçun takibi açısından herhangi bir önemi yoktur. Bireysel sendika özgürlüğünün korunduğu birinci fikradaki suçun cezası altı aydan iki yıla kadar hapis cezası şeklinde belirlenmiştir. İkinci fikradaki suçun cezası ise bir yıldan üç yıla kadar hapis cezası gerektirmektedir. İkinci fikradaki suçun cezasının daha yüksek olmasının nedeni, kolektif sendika özgürlüğüne saldırının dolaylı olarak üyelerin de menfaatine zarar vermesidir.

Suçun cezasının üst sınırı nedeniyle, diğer koşulların da gerçekleşmesi halinde suç nedeniyle yürütülen soruşturma sonunda şüpheli hakkında kamu davasının açılmasının ertelenmesi, yargılama sonunda sanık hakkında hükmün açıklanmasının geri bırakılması kararı verilebilir.

Suç, Asliye ceza mahkemesinin görevine girmektedir. CMK m.251/1'e göre birinci fikradaki suçun cezasının üst sınırı iki yıl veya daha az süreli hapis cezasını gerektirdiğinden, bu suç basit yargilama usulüne tabidir.

$\mathrm{Bu}$ suç bakımından yetkili mahkeme, kişinin tehdit edildiği veya cebredildiği yer mahkemesidir. Sendikal faaliyetin engellenmesi halinde ise faaliyetleri engellenen sendika şubesinin olduğu yer mahkemesi yetkilidir. Sendikanın birden çok yerdeki şubelerinin faaliyetlerinin engellenmek istenmesi halinde, davaların birleştirilerek görülmesi gerekir. Sendika genel merkezinin ya da konfederasyonun faaliyetlerinin engellenmesi halindeyse sendika genel merkezinin bulunduğu yer mahkemesi yetkili olmalıdır.

Birinci fikradaki suç açısından sendikal hakkı engellenen gerçek kişi suçun mağduru sıfatıyla, ilgili sendika tüzel kişiliği ise suçtan zarar gören sıfatıyla davaya katılabilir. Tehdit edilen bir kişinin sendikadan istifa etmesi halinde üye sayısı ve aidatı azalan sendikanın suçtan zarar gördüğü kabul edilmelidir. Bu durumda mağdur olan gerçek kişinin yanı sıra sendika tüzel kişiliğinin de suçtan zarar gören sıfatıyla açılan kamu davasına müdahil olması gerekir. Ancak Yargitay Ceza Genel Kurulu;

“Gerçek kişilere karşı işlenebilen ve bireysel sendika özgürlüğ̈̈nü koruyan TCK'nın 118. maddesinin ilk fikrasındaki sendikal hakların kullanılmasının engellenmesi suçu nedeniyle sendikanın faaliyetlerinin engellenmesi, üyelerini, aidat gelirlerini kaybetmesi veya toplu iş sözleşmesi yapma yetkisini kazanamama ya da kaybetme gibi dolaylı olarak zarar görme ihtimali bulunsa da, bu suçla korunan hukuki yararın bireysel sendika hakkı olması, sendika tüzel kişiliğinin suçtan zarar gören olarak kamu davasına katılması için doğrudan bir zarar görmesinin gerekmesi ve mevzuatta sendikaların bu suçlardan açılan kamu davalarına katılmasını özel olarak düzenleyen bir hükmün bulunmaması karşısında, ilgili sendikanın TCK'nın 118. maddesinin birinci fikrası

\footnotetext{
${ }^{68}$ Bkz. EVIK, s.215.

${ }^{69}$ Bkz. FINCAN, s.63; ERSOY, s.490-491.

${ }^{70}$ Bkz. EVIK, s.216.
} 
kapsamındaki suçlarda, suçtan zarar gören olarak kamu davasına katılma hakkının ve gelinen aşamada gerekçeli kararın ilgili sendikaya tebliğine gerek bulunmadiğı kabul edilmelidir."

şeklindeki yorumuyla bireysel sendikal faaliyet hakkının ihlal edilmesi halinde, mağdurun üyesi olduğu sendikanın davaya katılma hakkı olmadığ 1 yönünde karar vermiştir. ${ }^{71} \mathrm{Bu}$ kararın isabetli olduğu söylenemez. Sendika üyelerinin sendikal faaliyetleri nedeniyle tehdit edildiği bir olayda ilgili sendikanın bu suç nedeniyle zarar görmediğini söylemek isabetli değildir. Çünkü sendika bu nedenle üyelerini kaybedebilir, yeni üye kaydı yapamayabilir, yöneticilerin faaliyetlerin engellenmesi nedeniyle sendika karar alamayabilir ya da genel kurul faaliyetleri aksayabilir. Üyelerin zorla sendikadan istifa ettirilmesi, sendikanın faaliyetlerini aksatabileceği gibi sendikanın aidat geliri de azalacaktır. Sendika yöneticilerinin sendikal haklarının engellenmesi ise sendika açısından daha ağır sonuçlar doğurabilir. Yargıtay'ın bu kararı, madde metninde kolektif ve bireysel sendikal hakların birlikte korunduğu, sendika tüzel kişiliğinin sendika faaliyeti ile üyelerin sendikal faaliyetine ilişkin olarak bu suçla korunan hukuki yararın birbirini tamamladığı gerçeğine aykırıdır.

İkinci fikradaki suç açısından faaliyetleri engellenen sendikanın yanı sıra bu amaçla tehdit edilen ya da cebredilen gerçek kişiler de mağdur sıfatıyla davaya katılma hakkına sahiptirler. Her iki suç da re'sen takip edilen suçlardan olduğundan, davaya katılmak hakkı olanların katılıp katılmamalarının ya da katılmadan vazgeçmelerinin muhakemeye etkisi yoktur.

\section{SONUÇ}

Sendikalar, 19. yüzyılda işçilerin çalışma hayatında ve iş ilişkilerinde işvene karşı daha güçlü olmak için bünyesinde örgütlendikleri tüzel kişiler olarak ortaya çıkmış olsa da günümüzde işçilerin yanı sıra işverenler de kendi menfaatlerini korumak amacıyla işveren sendikası kurarak sendikaya üye olmak hakkına sahiptirler. Bu doğrultuda 6356 sayılı Sendikalar ve Toplu İş Sözleşmesi Kanunu'nda sendika (m.1/ g);

"İşçilerin veya işverenlerin çalışma ilişkilerinde, ortak ekonomik ve sosyal hak ve çıkarlarını korumak ve gelişstirmek için en az yedi iş̧̧ veya işverenin bir araya gelerek bir işkolunda faaliyette bulunmak üzere oluşturdukları tüzel kişiliğe sahip kuruluşlar"

şeklinde tanımlanmıştır.

İşçilerin ve işverenlerin sendika kurmak ve sendikaya üye olmak hakkı, Uluslararası Çalışma Örgütü (ILO) Sözleşmeleri'nin yanı sıra Avrupa İnsan Hakları Sözleşmesi (AİHS, m.11) ve Anayasamızda (m.51) güvence altına alınmıştır. Bireylerin sendikaya üye olmaları ve bireysel sendika haklarıyla sendikaların faaliyetlerinin ayrıntıları 6356 sayılı Kanun ile 4688 sayılı Kamu Görevlileri Sendikaları ve Toplu Sözleşme Kanunu'nda düzenlenmiştir. Bu düzenlemelerde yer alan sendikal hakların engellenmesiyle ilgili olarak 765 sayılı mülga TCK' da açık bir düzenleme yokken 5237 sayılı TCK'da sendikal hakların kullanılmasının engellenmesi suçu, "Kişilere Karşı Suçlar" başlıklı ikinci kısımda, "Hürriyete Karşı Suçlar" başlıklı yedinci bölümde m.118'de düzenlenmiştir. TCK m.118'de birinci fikrada, kişilerin herhangi bir baskı görmeden sendikal haklarını kullanabilmeleri, ikinci fikrada ise yasalara göre kurulmuş olan bir sendikanın faaliyetlerinin engellenmeden devam edebilmesi güvenceye alınmıştır. Böylece aynı madde içinde hem bireysel hem de kolektif sendika özgürlügünün korunması amaçlanmıştır. Bu düzenleme nedeniyle TCK m.118'de maddi unsurları ve mağdurları birbirinden farklı ancak birbirini tamamlayıcı nitelikte iki ayrı suç söz konusudur.

Birinci fikrada düzenlenmiş olan sendikal faaliyet hakkının engellenmesi suçunun hukuki konusunu uluslararası sözleşmeler ve anayasada güvence altına alınmış olan sendika kurmak, sendika bünyesinde örgütlenmek ve sendikal faaliyetlere katılmak hakkı oluşturmaktadır. Bu hak kişilerin herhangi bir hukuka aykırı müdahale olmaksızın sendika üyesi olup olmamak, sendikal faaliyette bulunup bulunmamak, sendika yönetiminde görev alıp almamak ve üyesi oldukları sendikadan istifa edebilmek yönündeki haklarını kapsamaktadır. Bu suçun faili herhangi bir gerçek kişidir. Suçun mağduru ise sendika kurmak, sendika üyesi olmak, sendikal faaliyetlere katılmak ya da sendikadan istifa etmek yönünde cebredilen ya da tehdit edilen gerçek kişidir. Birinci fikradaki suçun gerçekleşmesi için, mağdurun sendikal faaliyet hakkını kullanmasının tehdit ya da cebir oluşturan davranışlarla engellenmesi gerekir. Somut olayda tehdidin ya da cebrin söz konusu olup olmadığı TCK m.106 ve m.108'e göre belirlenmelidir. Kullanılan cebrin, kasten yaralamanın neticesi sebebiyle ağırlaşmış hallerine neden olması halinde, fail bu sonuçtan da sorumlu olmalıdır. Bu suç açısından gerçekleşebilecek hukuka uygunluk nedeni, TCK m.24/1'deki kanunun hükmünün

\footnotetext{
${ }^{71}$ Yargitay Ceza Genel Kurulu'nun 17.9.2019 tarih ve 2019/18-285 E., 2019/554 K. sayılı kararı için bkz. Kazancı İçtihat Program1.
} 
ve yetkili makamın emrinin yerine getirilmesidir. Bu suç kasten işlenebilen bir suçtur. Birinci fikradaki suç açısından, mağdurun görevinden ayrılmaya zorlanması amacıyla cebir veya tehdit kullanılması arandığından, failin özel kasıtla hareket etmesi gerekir.

İkinci fıkradaysa sendika tüzel kişiliğinin faaliyetlerinin engellenmesi suç olarak düzenlenmiştir. $\mathrm{Bu}$ suçun hukuki konusu, sendika tüzel kişiliğinin ilgili mevzutta gösterilen faaliyetlerde bulunmasına ilişkin kamusal yarardır. Kanun metninde açıç̧a konfederasyon faaliyetlerinden söz edilmiş olmasa da sendikalar, konfederasyon bünyesinde örgütlenebildiklerinden, bu hükümle sendika konfederasyonlarının da sendikal faaliyette bulunma hakkının korunduğu kabul edilmelidir. Bu suçun faili herhangi bir gerçek kişi, suçun mağduru ise sendika tüzel kişiliğidir. Bu suç, tehdit, cebir ya da hukuka aykırı bir başka davranışla işlenebilir. Hukuka aykırı davranışın mutlaka suç olması gerekmez. Hileli davranışların yanı sıra özel hukuk kurallarına aykırı davranışlar, idari makamların hukuka aykııı emirleri ve sendikanın faaliyetlerinin önlenmesi amacıyla kamusal yükümlülüklerin aksatılması, üyelerin istifa etmesini sağlamak için iş ve sendika hukukuna aykırı yararlar vaad edilmesi de bu kapsamda değerlendirilebilir. Bu suç açısından gerçekleşebilecek olan hukuka uygunluk nedenleri, TCK m.24'te düzenlenmiş olan kanunun ve yetkili makamın emrinin uygulanması ve çok sınırlı da olsa zorunluluk hali olabilir. Bu suç ancak kasten işlenebilen bir suçtur. Birinci fikradaki suç açısından mağdurun cebredilmesi veya tehdit edilmesinin amacı sendikal haklarının kullanılmasını engellemek olduğundan, failde bu yönde özel kastın varlığı gerekir. Tehdit veya cebir kullanılmasının amacı mağdurun sendikal haklarının kullanılmasının engellenmesi değilse, fail tehdit veya cebir suçundan sorumlu olacaktır. İkinci fıkradaki suç yönünden ise genel kastın varlığı yeterlidir.

TCK m.118'de yer alan her iki suç açısından ağıllatıcı ya da hafifletici nedenlere yer verilmemiştir. Hürriyete karşı suçlar açısından ortak hüküm olan TCK m.119'daki ağırlatıcı nedenlerin uygulanacağı suçlar arasında da TCK m.118 sayılmamıştır. Uygulamada tereddüt edilmemesi için TCK m.119'da sayılan suçlar arasına sendikal hakların kullanılmasın engellenmesi suçunun eklenmesi gerekir. Çünkü somut olayda bu suçun işlenmesi sırasında TCK m.119'da sayılan nitelikli hallerin gerçekleşmesi olanaklıdır. Hürriyete karşı suçlarla ilgili olarak "Ortak hüküm" kenar başlıklı TCK m.119/2'de gerçek içtima hükmüne yer verilmiştir, ancak sendikal haklarının kullanılmasının engellenmesi suçuna TCK m.119/1'de sayılan suçlar arasında yer verilmemiştir. Buna rağmen uygulamada tereddüt edilmeden, sendikal hakların kullanılmasının engellenmesi amacıyla başvurulan cebir ağırlaşmış yaralama sonucunu doğurduğunda, failin hem TCK m.118'deki suçtan hem de ağırlaşmış yaralamadan dolayı sorumlu olması ve gerçek içtimaya gidilmesi gerekir.

Her iki suç da Asliye ceza mahkemesinin görevine girmektedir. Birinci fikradaki suçun cezasının üst sınırı iki yıl veya daha az süreli hapis cezasını gerektirdiğinden, basit yargılama usulüne tabidir. Bu suç bakımından yetkili mahkeme, kişinin tehdit edildiği veya cebredildiği yer mahkemesidir. Sendikal faaliyetin engellenmesi halinde ise faaliyetleri engellenen sendika şubesinin olduğu yer mahkemesi yetkilidir. Sendikanın birden çok yerdeki şubelerinin faaliyetlerinin engellenmek istenmesi halinde, davaların birleştirilerek görülmesi gerekir. Sendika genel merkezinin ya da konfederasyonun faaliyetlerinin engellenmesi halindeyse bunların genel merkezinin bulunduğu yer mahkemesi yetkili olmalıdır.

Yargıtay Ceza Genel Kurulu aksi yönde karar vermiş olsa da birinci fikradaki suç açısından sendikal hakkı engellenen gerçek kişinin yanı sıra üyesi olduğu sendikanın da suçtan zarar gören sıfatıyla davaya katılma hakkı olduğu kabul edilmelidir. İkinci fikradaki suç açısından faaliyetleri engellenen sendikanın yanı sıra bu amaçla tehdit edilen ya da cebredilen gerçek kişiler de mağdur sıfatıyla davaya katılma hakkına sahiptirler. Her iki suç da re'sen takip edilen suçlardan olduğundan, davaya katılmak hakkı olanların katılıp katılmamalarının ya da katılmadan vazgeçmelerinin muhakemeye etkisi yoktur. 


\section{KAYNAKÇA}

ANTOLISEI, Francesco: Manuale di Diritto Penale, Parte Speciale, (a cura di Luigi Conti), Vol.1, Milano 1986.

ARGUN, Fazilet Nurel: “Sendikal Hak ve Özgürlüklerin Hukuki Niteliğii”, Türkiye Barolar Birliği Dergisi, (1), 1995, s.5-23.

ARTUK, M. Emin/GÖKCEN, Ahmet/YENIDÜNYA, A. Caner: Ceza Hukuku Özel Hükümler, 7. Baskı, Turhan Kitabevi, Ankara 2006.

AYDIN, Mesut: “1982 Anayasasında Sendika Kurma Hakk1 ve Sınırlanması”, İstanbul Medipol Üniversitesi Hukuk Fakültesi Dergisi, (2), 2016, s.61-100.

AYDIN, Devrim: “Tehdit Suçu”, Ceza Hukuku Dergisi, (42), 2020, s.9-42.

BAYRAKTAR, Köksal/YILDIZ, Ali Kemal/KESKİN KİZİOĞLU, Serap/ZAFER, Hamide ve diğerleri: Özel Ceza Hukuku, C.3, Onikilevha Yay., İstanbul 2018.

ERDOĞAN, Irmak: “Ceza Hukukunun Sendikasızlaştırmayla Mücadelesi: Sendikal Hakların Kullanılmasının Engellenmesi Suçu”, Galatasaray Üniversitesi Hukuk Fakültesi Dergisi, (2), 2015, s.67-94.

ERSOY, Uğur: "Sendikal Hakların Kullanılmasının Engellenmesi Suçu (TCK m.118)", Gazi Üniversitesi Hukuk Fakültesi Dergisi, (2), 2016, s.471-515.

EVİK, Ali Hakan: "Sendikal Hakların Kullanılmasının Engellenmesi Suçu”, İstanbul Ticaret Üniversitesi Sosyal Bilimler Dergisi, (10), 2006, s.203-219.

FINCAN, Müslüm: "Sendikal Hakların Kullanılmasının Engellenmesi Suçu”, Türkiye Barolar Birliği Dergisi, (136), 2018, s.39-74.

HAFIZOĞULLARI, Zeki/ÖZEN, Muharrem: Türk Ceza Hukuku Özel Hükümler, Kişilere Karşı Suçlar, USA Yay., Ankara 2011

KAYA, Pir Ali/ULAŞ, Işın/YILMAZER, Ertuğrul: "Uluslararası İnsan Hakları Hukukunda Çalışma Hakkı", Sosyal Siyaset Konferansları Dergisi, (70), 2016, s.55-86.

MAHİROĞULLARI, Adnan: Dünyada ve Türkiye'de Sendikacılık, Ekin Yay., Bursa 2013.

ÖZBEK, Veli Özer/DOĞAN, Koray/BACAKSIZ, Pınar/TEPE, İlker: Türk Ceza Hukuku Özel Hükümler, 10.B., Seçkin Yay., Ankara 2016.

ÖZEN, Mustafa: "Bireysel Sendika Özgürlüğü ve Sendikal Hakların Kullanılmasının Engellenmesi Suçu”, Legal İş Hukuku ve Sosyal Güvenlik Hukuku Dergisi, (46), 2015, s.47-74.

SOYER, Sesim: "İş ve Çalışma Hürriyetinin İhlali ile Sendikal Hakların Kullanılmasının Engellenmesi Suçlarına İlişkin Bazı Düşünceler”, Hukuki Perspektifler Dergisi, (7), 2006, s.99-108.

TOROSLU, Nevzat/TOROSLU, Haluk: Ceza Hukuku Genel Kısım, Savaş Yay., Ankara 2015.

ÜZÜLMEZ, İlhan: Tehdit, Şantaj ve Cebir Kullanma Suçları, Turhan Kitabevi, Ankara 2007.

VIARO, Mario: "Violenza e Minaccia”, Novissimo Digesto Italiano, Vol. XX, Milano: 1976, s.967-976.

VINCIGUERRA, Sergio: il Codice Penale Tedesco, CEDAM, Padova 2003.

YARSUVAT, Duygun: Çalışma Ceza Hukuku, Sendika Özgürlüğüne Karşı Suçlar, Kanunsuz Grev ve Lokavt Suçları, Sermet Matbaası, İstanbul 1978.

YARSUVAT, Duygun: "Yeni Türk Ceza Kanunu'nun 117 ve 118. Maddelerinde Yer Alan İş ve Çalışma Hürriyetinin İhlali, Sendikal Hakların Kullanılmasının Engellenmesi Suçları”, Sicil İş Hukuku Dergisi, (7), 2007, s.141-143.

ZAFER, Hamide: Ceza Hukuku Genel Hükümler, Beta Yay., İstanbul 2021.

Web Sayfalart:

Adalet Bakanlığı 5237 sayılı Türk Ceza Kanunu tanıtım sitesi, http://www.ceza-bb.adalet.gov.tr. Son erişim: 27.07.2021.

Kazancı İçtihat Bilgi Bankası, http://www.kazanci.com/kho2/ibb/giris.html. Son erişim: 27.07.2021 